\title{
DURATION OF THE MONITORING OF INTRACRANIAL PRESSURE CONCERNING THE PRESENCE OF INTRACRANIAL HYPERTENSION
}

\author{
Aleksandar Kostić1,2, Ivan Stefanović1,2, Radisav Mitić1,2, Miša Radisavljević1,2, \\ Luka Berilažić ${ }^{1}$, Slavko Živković ${ }^{2}$
}

\begin{abstract}
Duration of intracranial pressure (ICP) monitoring depends on the clinician 's necessity for the data that influence type and length of the management of intracranial hypertension (ICHT). On the other hand, it is also affected by the possibility of the development of the infection, which is very often fatal when it occurrs in the central nervous system.

A prospective study of the 32 patients with severe brain trauma (SBT) that had intracranial pressure (ICP) monitoring is presented in here. There were 22 patients with intracranial hypertension (ICHT) and 10 without it. In the ICHT group, the monitoring lasted $5.81 \pm 2.70$ and $4.45 \pm 1.81$ in the control group. We have not found a significant difference in the duration of the ICP monitoring between two groups $(t=1.71, p>0.05)$. Patients with ICHT had significantly shorter survival than the control group $(p=0.04)$.

It seems that need for prolonged monitoring of the patients with ICHT is suppressed by their shorter survival, comparing to brain-injured patients with normal intracranial pressure.

Acta Medica Medianae 2019;58(1):33-38.
\end{abstract}

Key words: monitoring, intracranial pressure, brain injuries

${ }^{1}$ Clinic for Neurosurgery, Clinical Center Niš, Serbia

${ }^{2}$ University of Niš, Faculty of Medicine, Niš, Serbia

Contact: Aleksandar Kostić

Blvd dr Zoran Djindjić 81, 18000 Niš, Serbia

E-mail: aleko018@yahoo.co.uk toring usually means a bigger chance of successful treatment of the SBI patients.

The aim of this study was to show duration of ICP monitoring in both traumatized patients with ICHT and traumatized patients without it, and to find if there is a significant difference between them.

\section{Patients and methods}

In this prospective study, 32 patients underwent intracranial pressure monitoring after suffering SBI. It is defined as a brain injury resulting in an altered consciousness represented in the Glasgow Coma Scale from 3 to 8 . Three stands for deep coma and 8 for state of motor, verbal and eye response when patients are aroused. Twenty -two of them had intracranial hypertension and 10 did not have it. They were divided into two groups: the group with intracranial hypertension (ICHT) and the control group. All of the patients had GCS $\leq 8$ or abnormal CT scan of the brain in terms of present mass lesions. Mass effects that had been shown in the CT with midline shifting bigger than $5 \mathrm{~mm}$ were surgically explored (external or internal decompression). Patients with CT findings of no mass effect large enough and with ICHT were treated conservatively, in the Intensive care Unit.

ICHT was defined as a state of permanently elevated values of ICP, higher than $20 \mathrm{mmHg}$, for a period of time longer than 2 hours. We made continuous monitoring of the ICP by recording the data on an hourly basis and readings were performed from 
the display device (Codman ICP Express). Seventeen patients had ICP monitor implanted subdural, 11 intraparenchymal and 4 intraventricular.

In all of the patients specific therapy options were administered in order to restore andlor preserve normal ICP, but in fifteen of them surgery had to be performed. Duration of the ICP monitoring lasted until its normalization, and then for 48 to 72 hours more, or, in some cases until the death occurs. In the patients where there was no intracranial hypertension initially, patients were monitored for another 48 to 72 hours, preemptively.

Besides general treatment measures, we provide specific and ultimate types of measures. The specific measures included: 1 . deep sedation and/or relaxation (fentanyl, vecuronium), 2. Drainage 3 to 5 $\mathrm{ml}$ of CSF (in cases of intraventricular placed systems), 3. mannitol bolus at first and then application intravenously for 6 hours, 4. Hyperventilation to $\mathrm{pCO}_{2}=30-35 \mathrm{mmHg}$. Ultimate treatments that we have used were: 1 . treatment with high doses of barbiturates (barbituric coma) 2. Hyperventilation to $\mathrm{pCO}_{2}=25-30 \mathrm{mmHg}$, 3. operation: internal or exterternal decompression. Appropriate nutritional support, glycemic control, and peptic ulcer prophylaxis were provided to all of the patients in the study. Internal decompression of traumatic mass lesions was done in 22 patients according to general neurosurgical indications.

For the quantitative statistical analysis Excel program from Microsoft Office, a software package was used for the tabular and graphical presentation of data. The calculations were performed using the SPSS program version 10.0. In all analysis the limits of statistical significance as the default error estimates of 0.05 or $5 \%$. For a comparison of numerical values between the two groups, we used the Student t-test for independent samples. Comparison of representation of certain modes of attribute characteristics between the two groups was performed by Fisher test.

\section{Results}

There were $29(90.62 \%)$ male patients and only 3 female $(9.38 \%)$ in the study group. The average age of the patients was $40.97 \pm 21.70$. Average GCS in the study patients was $6.29 \pm 2.11$. We have determined ICHT in $22(68.75 \%)$ of the monitored patients, $10(31.25 \%)$ of them did not meet the criteria of intracranial hypertension, and that was the control group. In $13(59.10 \%)$ patients ICHT was recorded in first 24 hours after trauma and in 9 $(40.90 \%)$ it was recorded afterwards. The average period of time from injury until insertion of the ICP probe was 0.68 days.

In the ICHT group of the patients, ICP monitoring lasted $5.81 \pm 2.70$ days, minimal 2 days, and maximum 10 days (Graph 1). In the control group duration of the monitoring was $4.45 \pm 1.81$ days, minimum 3 days and maximal 9 days (Graph 2).

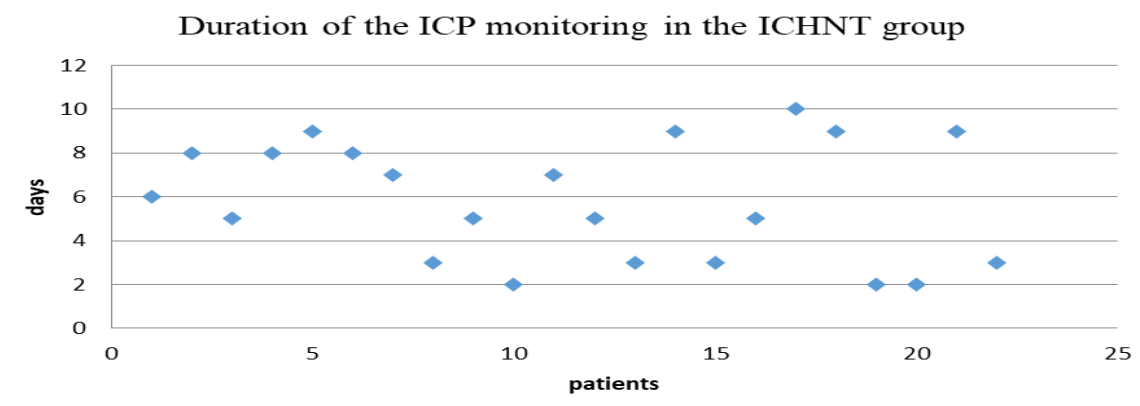

Graph 1. Distribution of duration (days) of the ICP monitoring in patients with ICHTN

Duration of the ICP monitoring in the control group

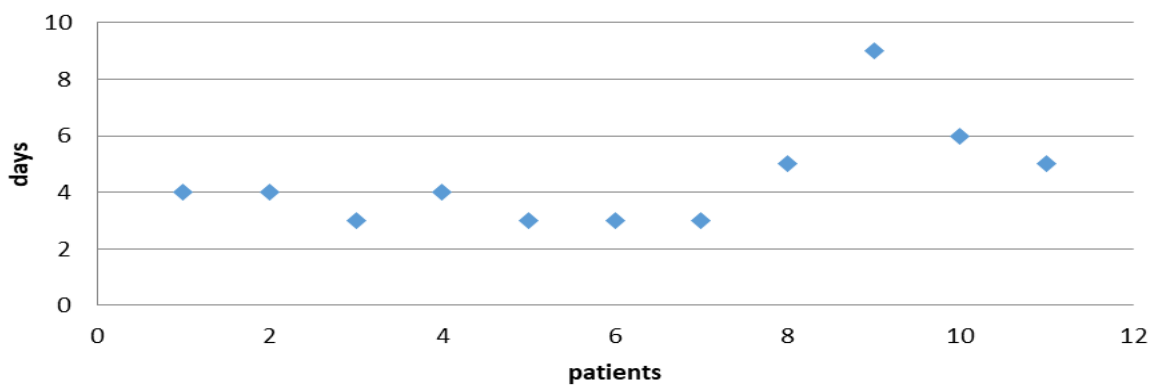

Graph 2 Distribution of the duration of the ICP monitoring in the control group 
There was no significant difference in duration of the monitoring between ICHT and control group ( $t=1.71$ and $p>0.05$ ) (Graph 3).

Percentage of the survived patients was significantly lower in patients with ICHT (Fisher test. $\mathrm{p}=$ 0,04; $\mathrm{p}<0,05$ ) (Table 1).
There were 20 registered complications during treatment of the study group. The most frequently pulmonary complications occurred, in 11 out of 32 patients $(34.37 \%)$, while all others were very rare. In nine patients pneumonia occurred and in two mechanical pneumothorax occurred. No CNS infections were noted (Table 2).

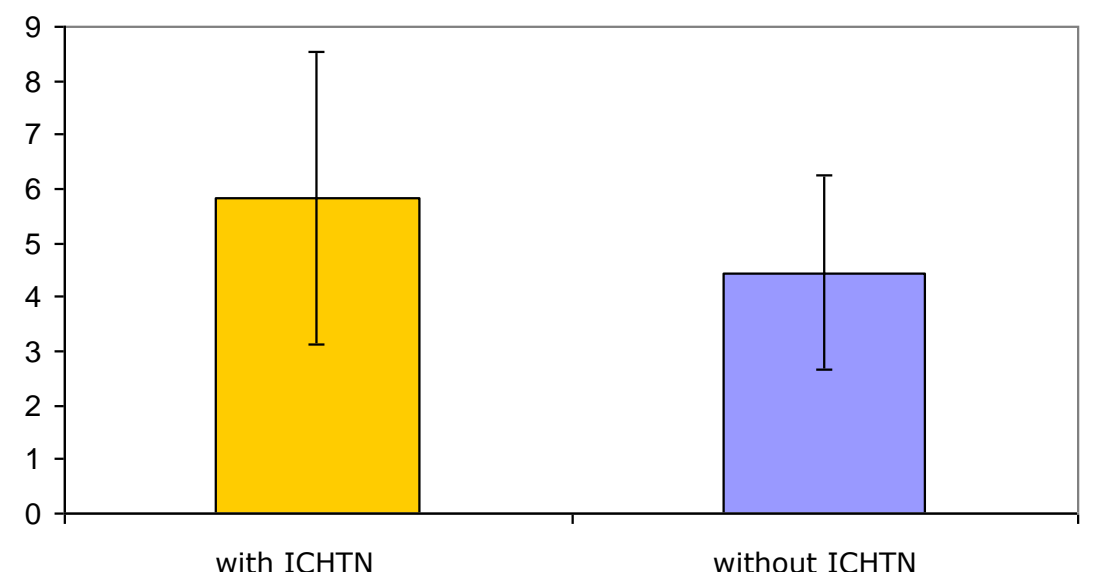

Graph 3. Comparison of duration of the ICP monitoring between ICHTN and control group (Xsr $\pm S D$ )

Table 1. Deceased vs survived ratio in study group considering the ICHTN

\begin{tabular}{||c|c|c|c|c|c||}
\hline \hline Monitoring ICP & $\mathrm{N}$ & deceased & \% deceased & survived & \% survived \\
\hline \hline with ICHTN & 22 & 13 & 59.10 & 9 & 40.90 \\
\hline without ICHTN & 10 & 2 & 20.00 & 8 & 80.00 \\
\hline \hline$\Sigma$ & 32 & 15 & & 18 & 56.25 \\
\hline \hline
\end{tabular}

Table 2. General complication during treatment of SBI and ICP monitored patients

\begin{tabular}{|c|c||}
\hline Complication & ICP monitored patients \\
\hline \hline Pneumonia & 9 \\
\hline Mechanical pneumothorax & 2 \\
\hline Thrombophlebitis & 2 \\
\hline Osteomyelitis & 1 \\
\hline CSF leaking & 1 \\
\hline Infection of the digestive tract & 4 \\
\hline Seizures & 1 \\
\hline CNS infections & - \\
\hline$\Sigma$ & 20 \\
\hline
\end{tabular}

\section{Discussion}

A headache, nausea, and vomiting, symptoms of the elevated ICP, are impossible to elicit in coma- tose patients. Papilledema, a clinical sign of intracranial hypertension is uncommon after the head injury, even in patients with documented elevated ICP (2). Brain edema CT scan signs, such as midline shift and 
compressed basal cisterns, are associated with increased ICP, nevertheless, intracranial hypertension can occur without those findings.

Several noninvasive ICP monitoring techniques have been proposed with the hope to replace the invasive techniques. Ocular sonography has been used to measure the changes in optic nerve sheath diameter to detect raised ICP, and it has been clinically shown that millimetric increases of the diameter correspond to increased ICP (3). Another method, pupillometry cannot be suggested for continuous ICP monitoring although it is a very useful method for screening patients with possibly increased ICP (4). Even today, invasive ICP monitoring is of the greatest significance in precise estimating both ICP and indirectly cerebral perfusion pressure (CPP). This gold standard, however, in most of the cases consists of the placement of an intraventricular catheter.

Duration of the ICP monitoring depends firstly on the severity of the injuries as they affect initial survival, then on the dynamics of normalization of the ICP, and at last but not the least, on the dedication of the clinician to struggle with the very frequent impregnable enemy (5). On the other hand, a patient's death or the occurrence of the complication of this intervention implies aborting the procedure.

The most common complication of ventriculostomy catheter placement is infection with an incidence of $5 \%$ to $14 \%$ (6). More than three decades ago, duration of ICP monitoring was shown to be associated with higher incidence of the infections, when Narayan found out that placement of an intraventricular catheter for a period of time longer than 5 days was accompanied with CNS infections in $85 \%$ (7).

The use of antibiotic-coated ventriculostomy catheters has been shown to reduce the risk of infection from $9.4 \%$ to $1.3 \%$ (8). In our study, we did not use catheters coated with antibiotics, but in the majority of the cases, we used subdural emplacement of the catheter, not intraventricular. Our patients had no case of infection. It seems that subdural location of the catheter's tip is less associated with infection than intraventricular. However, reviewing the literature showed us no paper dealing with this issue. Another reason for the absence of the infection could be that we never prolonged ICP monitoring more than 10 days. In his study of 595 patients, Park et al. found out that relationship between duration of catheterization and infection is a fact. Nevertheless, in a group of 213 patients with prolonged ventricular drainage of 10 days or more, a non-linear increase in daily infection rate was observed over the initial 4 days but remained constant despite prolonged catheter use (9). Prophylactic antibiotic therapy seems to be of some benefit as some studies have shown (10) and we have implemented it in our therapy during all the time of the monitoring of the patients. Factors that are not associated with infection are the insertion of the catheter in the neurologic ICU, drainage of CSF, and the use of steroids. No reduction of the infection rate was achieved when prophylactic replacement of the catheters was practiced during ICP monitoring comparing to the group where they were in place all the time (11). Neither did we replace monitor catheters, during the period of ICP monitoring.
Secondly, the frequent complication of ventriculostomy catheters is hemorrhage in $1.4 \%$ cases (12). However, such hemorrhages are unusually large, rarely the cause of neurological deterioration, and almost never require surgical removal. On the other hand, malfunction, obstruction, and malposition always require replacement or removal of the device's catheter.

Other complications that occurred during the treatment of the ICP monitored patients were not implied in the process of the monitoring, as they had not been caused by this diagnostic procedure. The exception was if they directly influenced mortality of the patients. At the first place, pulmonary complications were noticed, pneumonia and pneumothorax, while other types of complications were rare. Prevalence of the pulmonary complications in critically ill neurological patients is well known (13). Besides polytraumas that often include direct chest trauma and consequently rib fractures, lung contusions, and pneumo or hemothorax, the most commonly noted respiratory complications are pneumonia, acute respiratory distress syndrome, pulmonary embolism, and mechanical pneumothorax. The main cause of these complications is the inability to protect the airway, low mobility of the patients, disruption of natural defense barriers in the patients with a depressed level of consciousness (13).

Our prime expectation was that patients with SBI that had ICHTN would have a significantly longer period of time ICP monitored, but results showed that duration was only 1.5 days longer $(p>0.05)$. This could be due to the fact that patients with $\mathrm{ICH}$ TN lived shorter than the control group ( $p=0.04)$, despite all the efforts of the clinicians and staff at the ICU to prolong the survival of the patients. ICHTN is well known negative survival factor in SBI patients, no matter if they are in the deepest coma (14) or not (15). This fact also shows that the level of control of the ICP in SBI patients is not satisfactory despite all therapy options implemented during this study or elsewhere (15).

\section{Conclusion}

Invasive ICP monitoring remains the golden standard in the management of the severe brain injured patients despite attempts to be replaced by noninvasive monitoring methods. Longer monitoring, intraventricular placement of the catheter and omission of the antibiotic application are likely to enhance the chance for infection. It seems that need for prolonged monitoring of the patients with ICHT is suppressed by their shorter survival, comparing to brain -injured patients with normal intracranial pressure.

\section{Conflicts of interest}

The results presented in this paper have not been published previously in whole. The authors report no conflicts of interest. The authors alone are responsible for the content and writing of the paper. 


\section{References}

1. Oertel M, Kelly DF, Lee JH, McArthur DL, Glenn TC, Vespa $P$, et al. Efficacy of hyperventilation, blood pressure elevation, and metabolic suppression therapy in controlling intracranial pressure after head injury. J Neurosurg 2002; 97(5):1045-53.

[CrossRef] [PubMed]

2. Selhorst JB, Gudeman SK, Butterworth JF, Harbison JW, Miller JD, Becker DP. Papilledema after acute head injury. Neurosurgery 1985; 16:357-63. [CrossRef] [PubMed]

3. Geeraerts T, Duranteau J, Benhamou D. Ocular sonography in patients with raised intracranial pressure: The papilloedema revisited. Crit Care 2008; 12:150. [CrossRef] [PubMed]

4. MN Khan, H Shallwani, MU Khan, MS Shamim. Noninvasive monitoring intracranial pressure $-A$ review of available modalities. Surg-Neurol Int 2017; 8:51. [CrossRef] [PubMed]

5. Contant CF Jr, Narayan RK. Prognosis after head injury. In: Youmans JR, editor. Neurological surgery. 4th ed. Philadelphia: WB Saunders; 1996. P. 1792-812.

6. Mayhall CG, Archer NH, Lamb VA, Spadora AC, Baggett JW, Ward JD, et al. Ventriculostomy-related infections: a prospective epidemiologic study. N Engl ] Med 1984; 310:553-9. [CrossRef] [PubMed]

7. Narayan RK, Kishore PRS, Becker DP, Ward JD, Enas GG, Greenberg RP, et al. Intracranial pressure: to monitor or not to monitor? A review of our experience with severe head injury. J Neurosurg 1982; 56(5): 650-9. [CrossRef] [PubMed]

8. Zabramski JM, Whiting D, Darouiche RO, Horner TG, Olson J, Robertson C, et al. Efficacy of antimicrobialimpregnated external ventricular drain catheters: a prospective, randomized, controlled trial. J Neurosurg 2003; 98:725-30. [CrossRef] [PubMed]

9. Park P, Garton HJL, Kocan MJ, Thompson BG. Risk of Infection with Prolonged Ventricular Catheterization. Neurosurgery 2004; 55:594-601.

[CrossRef] [PubMed]

10. Sonabend AM, Korenfeld Y, Crisman C, Badjatia N, Mayer SA, Connolly ES Jr. Prevention of ventriculostomy-related infections with prophylactic antibiotics and antibiotic-coated external ventricular drains: a systematic review. Neurosurgery 2011; 68(4):996-1005. [CrossRef] [PubMed]

11. Holloway KL, Barnes T, Choi S, Bullock R, Marshall LF, Eisenberg $\mathrm{HM}$, et al. Ventriculostomy infections: the effect of monitoring duration and catheter exchange in 584 patients. J Neurosurg 1996; 85:419-24.

[CrossRef] [PubMed]

12. Ko JK, Cha SH, Choi BK, Lee JI, Yun EY, Choi CH. Hemorrhage Rates Associated with Two Methods of Ventriculostomy: External Ventricular Drainage vs. Ventriculoperitoneal Shunt Procedure 2014; 54(7): 545-51. [CrossRef] [PubMed]

13. Lee K, Rincon F. Pulmonary Complications in Patients with Severe Brain Injury. Critical Care Research and Practice 2012. doi:10.1155/2012/207247. [CrossRef]

14. Krbila S, Waczulikova I, Sobona V, Zahorec R. Impact of intracranial pressure measurement on survival in patients with severe traumatic brain injury. Bratisl Lek Listy 2013; 114(12):696-701. [CrossRef] [PubMed]

15. Miller JD, Becker D, Ward JD, Sillivan HG, Adams WE, Rosner MJ. Significance of intracranial hypertension in severe head injury. JNS 2010; 112(2):503-16. [PubMed] 


\title{
TRAJANJE PRAĆENJA INTRAKRANIJALNOG PRITISKA UZIMAJUĆI U OBZIR PRISUTVO INTRAKRANIJALNE HIPERTENZIJE
}

\author{
Aleksandar Kostić1,2, Ivan Stefanović1,2, Radisav Mitić1,2, Miša Radisavljević1,2, \\ Luka Berilažić ${ }^{1}$, Slavko Živković ${ }^{2}$
}

${ }^{1}$ Neurohirurška klinika, Klinički centar Niš, Srbija

${ }^{2}$ Univerzitet u Nišu, Medicinski fakultet, Niš, Srbija

Kontakt: Aleksandar Kostić

Bulevar dr. Zoran Đinđić 81, 18000 Niš, Srbija

E-mail:aleko018@yahoo.co.uk

Trajanje praćenja intrakranijalnog pritiska (IKP) zavisi od potrebe kliničara da, potpomognut odgovarajućim podacima, modifikuje tip i dužinu terapije intrakranijalne hipertenzije. Sa druge strane, na monitoring IKP utiče mogućnost razvoja infekcije, koja je često fatalna kada zahvati centralni nervni sistem.

Prospektivna studija obuhvatila je 32 bolesnika sa teškom povredom mozga (TPM) kojima je praćen IKP. Bilo je 22 bolesnika sa intrakranijalnom hipertenzijom (IKHTN), a 10 bez. U grupi bolesnika sa IKHTN, monitoring je trajao 5,81 $\pm 2,70$ dana, a 4,45 $\pm 1,81 \mathrm{u}$ kontrolnoj grupi. Nismo našli značajnu razliku u trajanju praćenja IKP između ove dve grupe $(t=1,71, p>0,05)$. Bolesnici sa IKHTN su značajo kraće preživljavali povrede mozga od kontrolne grupe $(p=0,04)$.

Čini se da je potreba dužeg praćenja bolesnika sa IKHTN kompromitovana njihovim kraćim preživljavanjem u odnosu na kontrolnu grupu.

Acta Medica Medianae 2019;58(1):33-38.

Ključne reči: praćenje, intrakranijalni pritisak, teška povreda mozga 